\title{
Kesisteman Dalam Dewan Perwakilan Daerah Partai Golkar Provinsi D.I.Y
}

\author{
Sabirin \\ Fakultas Ilmu Sosial Dan Ilmu Politik, Universitas Gajah Putih, Indonesia \\ Email Korespondensi: abiegayo@gmail.com
}

\begin{abstract}
Abstrak: Penelitian ini adalah untuk mengungkapkan fenomena umum yang tergambar dari kehidupan kekuatan sosial politik (Orde Baru, Parpol dan Golkar) terkesan terlalu kaku, struktural, institusional dan formalistik. Seluruh kekuatan sosial politik baik secara diam - diam maupun terang - terangan diarahkan untuk memberikan dukungan berupa legitimasi yang kuat kepada pemerintahan Orde Baru. Runtuhnya rezim orde baru "Soeharto" selaku Ketua Dewan Pembina partai golkar pada tahun 1998 ternyata tidak membawa dampak negatif terhadap kesisteman partai Golkar DIY walaupun di tingkat pusat terjadi pergolakan yang sangat luar biasa, sehingga atas kebijakan anggota partai golkar di dewan pusat mendesak diadakannya Munaslub yang dihadiri oleh semua perwakilan partai golkar baik ditingkat kabupaten/kota maupun propinsi di seluruh Indonesia guna menata kembali (restrukturisasi) kesisteman partai. Penelitin ini menggunakan metode penelitian diskriptif. Fokus penelitiannya adalah derajat kesisteman (systemness) terdiri dari : Asal usul partai, sumber pendanaan, peran pemimpin partai, faksionalisme (pengelompokan), klientelisme (pertukaran dukungan). Jenis dan sumber data didapatkan dari data primer dan data sekunder. Populasi dan sample adalah pengurus DPD Partai golkar DIY. Teknik pengumpulan datanya yaitu melalui, dokumentasi serta wawancara langsung. Teknis analisis data yang di gunakan adalah teknis analisis data kualitatif. Nilai-nilai dan praktik demokrasi sangatlah penting bagi institusionalisasi demokratis dan perkembangan ketangguhan partai Golkar. Tingkat Kesisteman di DPD Partai Golkar Propinsi DIY khususnya, dalam proses internal organisasi partai politik menuju sebuah organisasi yang terlembaga secara mapan, kompleksitas, norma dan perilakunya berdasarkan nilai-nilai yang disepakati bersama yang ditentukan oleh dimensi derajat kesisteman (systemness).
\end{abstract}

Kata kunci; Partai Golkar; Kesisteman; Institusional Partai Politik.

Abstract: This research is to reveal general phenomena reflected in the life of socio-political forces (New Order, Political Parties and Golkar) which seem too rigid, structural, institutional and formalistic. All sociopolitical forces, either secretly or openly, were directed to provide support in the form of strong legitimacy to the New Order government. The collapse of the new order regime "Soeharto" as Chairman of the Golkar Party Trustees Council in 1998 did not have a negative impact on the DIY Golkar party system even though at the central level there was tremendous upheaval, so that the policies of the Golkar party members in the central council urged the holding of a Munaslub which attended by all Golkar party representatives both at district I city and provincial levels throughout Indonesia in order to restructure the party system. This research uses descriptive research method. The focus of his research is the degree of systemness consisting of: Party origins, funding sources, the role of party leaders, factionalism (grouping), clientelism (exchange of support). Types and sources of data were obtained from primary data and secondary data. Population and sample are the board of the DIY Golkar Party DPD. Data collection techniques, namely through, documentation and direct interviews. The data analysis technique used is qualitative data analysis technique. Democratic values and practices are very important for democratic institutionalization and the development of the Golkar party's resilience. System level in DPD Golkar Party Yogyakarta Province in particular, in the internal process of political party organization towards an organization that is well-established, its complexity, norms and behavior are based on mutually agreed values which are determined by the dimension of systemness.

Keywords: Partai Golkar; System; Institutional Political Parties.

Article History:

Received: 5-8-2020; Revised: 25-9-2020; Accepted: 10-10-2020 


\section{PENDAHULUAN}

Semangat kekaryaan yang terwujud di dalam bentuk pengakuan terhadap Partai Golongan Karya yang tumbuh ketika pembahasan dan penyusunan Undang-Undang 1945 sedang dilakukan. Namun kedudukannya secara formal belum diatur dengan tegas pada awal kemerdekaan, hingga keluarnya Maklumat Wakil Presiden (Rahagi, 2019). Pada tanggal 16 Oktober 1945 keluar Maklumat Wakil Presiden Nomor X, yang disusul kemudian dengan Maklumat Pemerintah tanggal 3November 1945, yang memberi kesempatan mendirikan partai - partai politik dengan ideologi yang beraneka ragam. Kehidupan politik dalam sistem multi partai tersebut berlangsung sampai tahun 1957 dalam zaman yang dikenal dengan sebutan zaman demokrasi parlementer atau demokrasi liberal (Akhbar et al., 2020). Dalam zaman ini kendali percaturan politik berada ditangan partai - partai politik. Kendati pemilu 1955 telah dilangsungkan namun tidak ada satupun partai politik yang cukup dominan mengendalikan parlemen maupun pemerintahan. Keadaan demikian mendorong setiap berbentuk kabinet koalisi secara silih berganti (Sumarwati, 2011).

Dalam suasana demikian antara tahun 1950-1957 tidak kurang enam kabinet silih berganti. Setiap kabinet baru melahirkan program baru. Program kabinet lama ada yang diteruskan tetapi lebih banyak yang dibatalkan, karena tidak sesuai dengan program partai politik yang berkuasa. Akibatnya banyak program yang sedang dalam pelaksanaan menjadi terlantar dan menimbulkan kerugian negara yang tidak sedikit. Pemerintah selalu ragu-ragu untuk melaksanakan programnya karena selalu dihantui oleh seringnya pergantian kabinet dalam waktu relatif singkat (Darmawan et al., 2012). Sejarah telah mencatat bahwa umur kabinet pada zaman demokrasi parlementer tersebut rata - rata kurang dari satu tahun. Oleh sebab itu dapatlah dimengerti bahwa tidak satupun kabinet tidak mempunyai waktu yang cukup untuk bekerja.

Sementara itu pemberontakan bersenjata dan tuntutan daerah terhadap Pemerintah Pusat makin meluas, seperti pemberontakan DI-TII di Jawa Barat, Jawa Tengah Aceh, Sulawesi Selatan dan Kalimantan Selatan serta pemberontakan PRRI/PERMESTA di sumatera dan sulawesi. Ketidakstabilan politik dan keamanan dan tidak terjaminnya keselamatan rakyat mendorong TNI mengambil tindakan - tindakan yang dianggapnya perlu seperti pemberlakuan undang - undang keadaan bahaya pada tahun 1957 (IKPNI, 2019). Dalam usaha pemulihan keamanan, TNI menyadari sepenuhnya bahwa keamanan tidak dapat dipulihkan dengan kekuatan senjata saja, karena gangguan keamanan itu berlatar belakang sosial politik. Salah satu langkah yang diambil oleh TNI adalah penggalangan golongan - golongan fungsional dengan maksud tersebut dapat diajak turut dalam usaha pemulihan keamanan. Ajakan TNI kepada golongan - golongan fungsional untuk bekerja sama mendapat sambutan positif dari golongan fungsional yang tidak berafiliasi kepada suatu partai politik. Mereka merasa bahwa perjuangan yang tepat untuk melaksanakan pengabdian terhadap masyarakat, bangsa dan negara.

Puncak pertentangan partai - partai politik dalam masa demokrasi perlementer adalah kegagalan Konstituante dalam menetapkan Dasar Negara 1959, pertentangan tersebut berpusat pada adanya partai - partai politik yang dengan gigih mempertahankan Pancasila sebagai dasar negara, tetapi ada pula partai - partai politik yang dengan gigih pula menghendaki dan memperjuangkan Syari'at Islam sebagai dasar negara (Nurdamarsah, 2018). Untuk menyelamatkan bangsa dan negara dari kekacauan dan kehancuran, maka Presiden Soekarno mengeluarkan Dekrit Presiden 5 Juli 1959 yang memberlakukan kembali UUD 1945 yang pembukaanya memuat Pancasila yang resmi dan asli sebagai dasar negara kita.

Dengan berlakunya UUD 1945, maka mulailah dirintis penyederhanaan partai politik. Pada permulaan tahun 1961 hanya diakui 10 partai politik, tetapi walaupun jumlah partai - partai politik telah berkurang ternyata tidak mengurangi pertentangan ideologi didalam masyarakat malahan pertentangan itu semakin meruncing. Hal ini disebabkan adanya format politik Nasakom (nasionalis, agama, komunis) yang di gagas oleh Soekarno, PKI yang menjadi tulang punggung struktur politik Nasakom itu menuntut agar semua lembaga negara dan lembaga kemasyarakatan, termasuk golongan fungsional dinasakomkan. PKI sebagai tulang punggung utama politik nasakom menjadi semakin dominan dalam percaturan politik nasional dan untuk menghadapi ancaman PKI maka didirikan Soksi, Kosgoro dan MKGR.(Suyatno, 2006)

Sebagai perlawanan terhadap tekanan - tekanan PKI dan dalam rangka UUD 1945, maka golongan - golongan fungsional yang tidak berafiliasi pada partai politik dan dengan dukungan TNI berjuang keras untuk memformalkan kehadiran didal masyarakat. Melalui perjuangan yang ulet dan 
terus - menerus dari golongan fungsional, berdasarkan peraturan presiden nomor 12 tahun 1959, diangkatlah 200 (dua ratus) orang wakil - wakil Golongan Karya di MPRS. Kemudian dengan Kepres Nomor 193 tahun 1964 diakuilah wakil - wakil golongan karya di Front Nasional. Dengan adanya pengakuan tentang kehadiran dan legalitas golongan fungsional di MPRS dan Front Nasional, maka atas dorongan TNI dibentuklah Sekretaris Bersama Golongan Karya (SEKBER GOLKAR) pada tanggal 20 Oktober 1964 dan tanggal ini merupakan hari lahirnya Golkar.

Setelah meletus peristiwa G.30.S/PKI maka TNI, Sekber Golkar, Pemuda, mahasiswa dan rakyat yang Pancasilais bangkit dengan serentak menumpas gerakan pengkhianatan G.30.S/PKI tersebut dan dalam waktu singkat gerakan tersebut dapat ditumpas habis. Pada awal pertumbuhan Partai Golongan Karya, serber Partai ini beranggotakan 61 organisasi fungsional, kemudian bertambah hingga mencapai 291 organisasi fungsional, karena golongan-golongan fungsional lainya sudah menyadari bahwa serber Golkar juga berlandaskan Pancasila dan Undang-Undang 1945 serta tujuan dan haluannya adalah Demokrasi Pancasila untuk mencapai masyarakat adil dan makmur.

Sementara itu proses kristalisasi dalam tubuh Sekber Golkar berjalan terus, dengan didirikannya Parmusi pada tahun 1968 maka sejumlah organisasi melepaskan diri dari Sekber Golkar. Disamping itu dibentuklah kelompok organisasi (Kino-Kino) sebagai pengelompokkan dari organisasorganisasi yang bergabung dalam Sekber Golkar. Proses kristalisasi ini berlanjut lagi dengan keluarnya peraturan menteri Nomor 12 tahun 1969. Dalam keadaan yang terkristalisasi demikian, Sekber Golkar memasuki Pemilu 1971 ternyata rakyat memberikan kepercayaan kepada Sekber Golkar, dimana Sekber Golkar meraih 62,79 \% suara Pemilih. Setelah golkar meraih kemenangan dalam pemilu 1971 maka sesuai dengan ketentuan dalam ketetapan MPRS mengenai perlunya penataan kembali kehidupan politik Indonesia pada tanggal 17 Juli 1971 Sekber Golkar mengubah dirinya menjadi GOLKAR (koran.tempo.co/, 2004).

Dalam memasuki Orde Baru maka untuk memantapkan dirinya diadakanlah Musyawarah Kerja Nasional I (MUKERNAS I) Sekber Golkar dari tanggal 9 sampai 11 Desember 1965. pada waktu itu Mukernas berhasil menyusun program perjuangan disegala bidang dalam rangka usaha menegakkan Orde Baru. Masa awal Orde Baru, Sekber Golkar tumbuh dan berkembang bersama - sama dengan eksponen - eksponen orde baru lainnya serta mempelopori pembaruan kehidupan politik berdasarkan konsepsi pelaksanaan Pancasila dan UUD 1945 secara murni dan konsekuen serta melaksanakan Pembangunan Nasional disegala bidang sebagai upaya pengisian cita - cita proklamasi.

Selama perjalanannya Golkar telah memposisikan diri sebagai kekuatan sosial politik pendukung Orde Baru. Hal ini tercermin dari setiap pelaksanaan Munas Golkar senantiasa menghasilkan keputusan yang memberikan dukungan terhadap program - program pemerintah. Dengan kata lain program organisasi selalu disingkronkan dengan program pemerintah dan mendapat dukungan serta legitimasi dari lembaga legislatif yang dikuasai oleh Golkar. Ada empat hal utama yang menjadi ciri golkar dimasa orde baru. Pertama, dikenal denagn istilah Sistem Tiga Jalur $(\mathrm{A}=$ ABRI, B=Birokrasi, G=Golkar). Kedua, dominannya peranan lembaga Dewan Pembina. Ketiga, pengambilan keputusan selalu dari atas (top down) dan Keempat sangat menghindari pemungutan suara (voting) untuk menentukan pimpinan organisasi disemua tingkatan atau dari Ketua Umum DPP sampai pada tingkat kepengurusan terbawah.

Fenomena umum yang tergambar dari kehidupan kekuatan sosial politik (Orde Baru, parpol dan Golkar) terkesan terlalu kaku, struktural, institusional dan formalistik. Seluruh kekuatan sosial politik baik secara diam - diam maupun terang - terangan diarahkan untuk memberikan dukungan berupa legitimasi yang kuat kepada pemerintahan Orde Baru. Kondisi tersebut tercipta akibat berkembangnya sistem politik yang menempatkan pembangunan ekonomi sebagai prioritas utama yang dikenal dengan nama pembangunanisme (developmentalisme). Hal ini diterima luas oleh sebagian besar elit dan massa. Salah satu syarat pembangunan ekonomi itu ialah adanya stabilitas politik dengan jalan mengurangi partisipasi politik dan membatasi kebebasan politik.

Setelah runtuhnya rezim orde baru yang berkuasa selama 32 tahun tersebut tentu saja mengimbas kepada partai politik Golkar yang selama ini diasumsikan menjadi pendukung utama dan setia rezim tersebut. Hal ini secara kasat mata terlihat pada masyarakat memandang negatif terhadap partai ini, bahkan didalam tubuh Golkar pada awal - awal reformasi juga masih diperparah dengan konflik internal yang terjadi didalam kepegurusan partai ini, serta keterlepasan Golkar dari TNI dan Birokrasi pasca reformasi berakibat Golkar tidak punya pilihan lain kecuali harus membangun kembali kelembagaannya. 
Partai politik adalah organisasi yang bagaimanapun juga memiliki aturan yang formal dan juga tujuan yang formal, namun proses dimana mereka menjadi terlembagakan tidaklah identik dengan bagaimana perkembangan partai yaitu dalam terminologi partai yang bersifat organisasional semata. Sementara dengan mempertimbangkan model organisasi partai yang membagi tipe partai ke dalam partai elit, partai massa dan partai kader, maka akan mengikis kelemahan pendekatan kepartaian selama ini yang cenderung melihat partai sebagai institusi yang homogen plus kompak, dan hanya memiliki satu kepentingan dan rasonalitas, sehingga diharapkan temuan terhadap persoalan-persoalan pengorganisasian kepartaian akan dapat lebih menemukan ketajamannya.

Menurut Katz dan Mair yang membagi wajah partai ke dalam tiga konteks, yaitu: pertama, Ranah Party on the Ground, kedua, Party in Central Office (Partai pada tingkat pusat), dan yang ketiga Party in Publik Office (partai yang berada dalam pemerintahan), yang diwakili oleh anggotaanggotanya yang mendapat kesempatan menduduki jabatan-jabatan publik. Dalam fokus penelitian ini adalah pada Party on the Ground sebagai obyek penelitian karena partai pada level ini berhadapan langsung dengan massa pada level grass-roots, yang akan berhubungan dengan bagaimana mengajak orang untuk memberikan suara dalam sebuah pemilu pada level ini partai menjadi ujung tombak cerminan partai politik secara total atau keseluruhan. Performance partai pada tingkat lokal, diasumsikan akan berpengaruh secara signifikan terhadap performance partai secara nasional.

Salah satu pendekatan yang dapat digunakan untuk mengetahui perkembangan partai politik di Indonesia adalah melakukan penaksiran (assessment) terhadap tingkat pelembagaan yang telah berlangsung dalam suatu partai politik. Pendekatan insitusionalisasi partai politik sebagaimana yang dikemukakan oleh Randall dan Svasand yang melihat institusionalisasi partai terbagi dalam empat aspek, yang terbagi dalam dimensi internal dan eksternal. Dalam analisis tentang institusionalisasi partai politik di Indonesia, penelitian ini hanya akan melihat dimensi internal dari teorisasi Randall dan Svasand, yakni aspek systemness (Derajat Kesisteman) dan value infusion.

Dimensi internal ini sangat penting, karena sebuah partai akan mampu berkompetisi dalam sebuah pemilu, maupun melaksanakan berbagai agenda dan fungsi yang dibebankan kepadanya, juga melakukan institusionalisasi secara eksternal jika secara internal partai telah terkonsolidasi dan terlembaga. Namun jika secara internal saja partai telah bermasalah, maka akan kecil harapannya partai dapat berkembang menjadi sebagaimana yang diinginkan oleh masyarakat. Dalam usaha mencapai cita - citanya partai Golkar melaksanakan kebijakan ditingkat Provinsi, Kabupaten dan Kota. Sebagai partai politik partai Golkar menjalankan fungsi - fungsi politik secara baik dan transparan, yaitu sebagai wadah penyalur kepentingan rakyat, alat pelatihan kader politik dan kader bangsa, sarana pendidikan politik, partisipasi politik rakyat serta komunikasi politik.

Sifat partai Golkar yang terbuka dapat dibuktikan dengan multi etnisnya anggota partai dimana setiap warga negara Indonesia dapat menjadi anggota partai Golkar tanpa membedakan suku, agama, ras dan antar golongan serta wujudnya dapat dilihat pada kebijakan sikap partai Golkar dalam memelihara kerukunan hidup beragama dan persaudaraan yang hangat diantara sesama warga negara yang berlainan latar belakang budaya, suku atau rasnya. Oleh karena itu partai golkar akan terus mendorong terciptanya partisipasi politik yang kuat dan mengakar ditengah - tengah masyarakat, sehingga didalam diri kader dan anggota Golkar akan tumbuh rasa memiliki serta akan memperkuat posisi partai di daerah, dengan ini Pimpinan Partai di Daerah dapat mengambil inisiatif tanpa menunggu instruksi dari pusat, karena seiap kebijakan pusat belum tentu cocok dengan kondisi di daerah yang sangat beraneka ragam.

Berdirinya Partai Golkar Propinsi DIY tidak dapat dilepaskan dari dinamika politik pada level pusat. Meskipun dalam paradigma terbarunya Golkar sekarang tanpa malu-malu lagi menyebut dirinya sebagai Partai, yang demokratis, moderat, yang mengakar dan terpisah dari pemerintah, namun sebagaimana secara formal ditulis dalam AD/ART-nya. Keberadaan partai golkar Propinsi Daerah Istimewa Yogyakarta pada pasca orde baru secara umum mirip dengan kondisi partai ini di wilayah lain, Golkar menghadapi perombakan format politik yang menyebabkan hilangnya hak - hak istimewa penting yang menjadi pilar kemenangannya selama pemilu orba. Dengan lepasnya hak - hak istimewanya, golkar mengalami penurunan kualitas perolehan suaranya dalam jumlah yang besar.

Namun demikian secara kualitas kekuatan Golkar tetap harus diperhitungkan oleh partai lain karena ternyata hilangnya hak - hak istimewa ini tidak serta merta membuat Golkar menjadi partai yang lemah. Golkar tetap mempunyai pengaruh besar kedalam menentukan arah dinamika perpolitikan di Yogyakarta. 
Penelitian ini mengambil Propinsi Daerah Istimewa Yogyakarta sebagai lokasi penelitian, mengingat Yogyakarta adalah sebuah provinsi yang predikat istimewanya di dapatkan karena klaim atas iklim intelektualitasnya yang cukup tinggi sehingga banyak disebut sebagai Kota Pelajar. Hal ini tidak lepas dari banyaknya lembaga pendidikan dari tingkat dasar hingga perguruan tinggi yang ada di Provinsi DIY dan Kota Yogyakarta sendiri, Sehingga yogyakarta mempunyai tingkat Sumber Daya Manusia yang cukup tinggi untuk mempengaruhi sebuah iklim politik. Asumsi inilah yang menjadi dasar bagi penulis untuk memilih provinsi DIY sebagai lokasi penelitian. Berdasarkan pemaparan latar belakang permasalahan di atas, maka dapat dirumuskan bahwa permasalahan dalam penelitian ini sebagai berikut: Bagaimana Derajat Kesisteman (Systemness) di DPD Partai Golkar Propinsi Daerah Istimewa Yogyakarta? Adapun tujuan dari penelitian ini adalah untuk mengungkapkan fenomena umum yang tergambar dari kehidupan kekuatan sosial politik, Orde Baru, Parpol dan Golkar dan untuk menganalisis Intitusional partai golkar pasca munaslub golkar tahun 1998 serta derajat kesisteman Partai Golkar.

\section{METODE PENELITIAN}

Penelitin ini menggunakan metode penelitian kualitatif diskriptif. Prof. Dr. H. Noeng Muhadjir mengemukakan bahwa Penelitian kualitatif umumnya mengambil sampel lebih kecil, dan pengambilannya cenderung memilih hal yang dimaksud daripada acak. Penelitian kualitatif lebih mengarah ke penelitian proses daripada produk dan biasanya membatasi pada satu kasus (Berutu et al., 2017). Dalam penelitian deskriptif menjelaskan bahwa suatu metode penelitian untuk meneliti suatu kelompok manusia, suatu obyek, suatu sistem, pada peristiwa sekarang. Dengan tujuan untuk membuat deskripsi atau gambaran secara faktual dan sistematik mengenai data, fakta, dan sifat serta hubungan yang diteliti. Unit analisa data dalam mengumpulkan data yang digunakan adalah di kantor Dewan Pimpinan Daerah (DPD) Partai Golkar Propinsi DIY. Karena data dan informasi yang tersedia terdapat di kantor DPD Partai Golkar Propinsi DIY. Data primer adalah data dan informasi yang diperoleh melalui keterangan dari pihak-pihak yang kompeten dan berpengaruh terhadap masalah yang ada dalam penelitian ini serta pihak-pihak yang terkait dengan penelitian ini. Pihak-pihak yang berkompeten ini adalah pihak atau individu yang mempunyai tingkat pengaruh yang tinggi didalam DPD Partai Golkar Propinsi DIY. Data sekunder adalah data yang diperoleh dari berbagai catatan, buku-buku, artikel-artikel ilmiah, koran dan dokumen lainnya yang berhubungan dengan tema penelitian.

Sementara itu untuk teknik pengumpulan data yang digunakan adalah interview yang merupakan teknik mengumpulkan data dengan cara melakukan wawancara dan bertanya langsung kepada pengurus DPD Partai Golkar Propinsi Daerah Istimewa Yogyakarta, Peranan pemimpin yang dominan akan menimbulkan akibat buruk apabila si pemimpin menggunakan kharismanya untuk melanggengkan dominasinya, disisi lain peranan dominan pemimpin akan menimbulkan akibat positif apabila si pemimpin menggunakan kharismanya membangun kesisteman dalam partai. Selanjutnya menggunakan dokumentasi merupakan salah satu cara pengumpulan data dengan mengumpulkan informasi menganai hal-hal atau variable dalam penulisan penelitian ini melalui berbagai literatur, peraturan perundang-undangan, dokumen-dokumen, notulen rapat, catatan harian dan lain sebagainya.

Metode sampling yakni, metode dengan memberikan kuesioner kepada suatu obyek tertentu. Akan tetapi dalam penulisan penelitian ini penggunaan metode sampling hanya sebagai alternatif cadangan untuk mendapatkan data itupun terbatas dalam jenis purposive sampling, yaitu metode dengan cara membagikan kuesioner kepada beberapa pihak yang berkompeten yang berkaitan dengan tema penelitian.

\section{HASIL DAN PEMBAHASAN \\ Institusionalisasi Internal Partai Golkar}

Sesuai skema institusionalisasi partai dalam perspektif Randall dan Svasand ada beberapa ukuran yang bisa dipergunakan untuk melihat seberapa terinstitusionalkah sebuah partai politik, yang terbagi ke dalam dimensi internal dan eksternal. maka ada dua aspek yang akan dilihat, yaitu systemness dan value infusion. Oleh karena itu dalam penelitian ini hanya akan melihat dari aspek Systemness Derajat Kesisteman Dalam Partai Politik Golkar DPD Propinsi daerah Istimewa Yogyakarta. 


\section{Systemness}

Aspek systemness atau derajat kesisteman, yang berbicara tentang proses pelaksanaan fungsifungsi partai politik, termasuk penyelesaian konflik, yang dilakukan menurut aturan, persyaratan, prosedur, dan mekanisme yang disepakati dan ditetapkan dalam dokumen peraturan partai, misalnya Anggaran Dasar dan Anggaran Rumah Tangga partai politik.

Derajat institusionalisasi partai tergantung pada kemampuannya mengembangkan insentif dan disinsentif untuk menjalankan kesepakatan bersama tersebut. Lima aspek pengembangan organisasi nampaknya relevan untuk melihat dimensi ini. Kelima hal tersebut antara lain adalah bagaimana cara organisasi tumbuh dan berkembang, sumber daya organisasi terutama dari segi pendanaan, peran individual pemimpin berbanding organisasi partai, peran faksi-faksi berbanding partai secara keseluruhan, dan dampak klientilisme.

\section{Sejarah Pembentukan Dan Perkembangan Partai Golkar Propinsi DIY}

Terminologi partai partai politik sebenarnya masih menjadi perdebatan dikalangan ilmuwan politik. Paige Johnson Tan sependapat dengan Giovanni Santori membuat definisi partai politik secara longgar, yakni kelompok politik apa saja yang ikut serta dalam pemilu dan mampu menempatkan orang - orangnya dalam jabatan - jabatan publik. Tujuan didirikannya partai politik karenanya adalah untuk meraih jabatan politik serta untuk mendapatkan kekuasaan politik dan mengontrol proses perumusan kebijakan.

Katz dan Mair, adalah orang pertama yang mempertimbangkan perlunya menunjukkan heterogenitas konteks yang dihadapi partai. Wajah organisasi pertama adalah partai pada level akar rumput (party on the ground). Pada level ini partai menghadapi konteks lokal, partai lokal, pendukung, serta masyarakat pemilih. Wajah organisasi yang kedua adalah partai pada level pusat. Pada level ini partai menghadapi konteks nasional, partai-partai lain, dan negara. Sedangkan wajah organisasi yang ketiga adalah partai di pemerintahan (party in public office). Pada level ini partai menghadapi konteks dalam pemerintahan, fraksi-fraksi lain, komisi, dan negara.

Awal berdirinya Partai Golkar di Propinsi Daerah Istimewa Yogyakarta sebenarnya tidak dapat dilepaskan dari konteks dinamika politik pada level pusat. Meskipun dalam paradigma terbarunya partai Golkar sekarang ini mengaku menyebut dirinya sebagai Partai yang demokratis, moderat, yang berakar dan terpisah dari pemerintah, akan tetapi, pada dasarnya keberadaan partai Golkar saat ini secara formal merupakan keberlangsungan yang ditulis dalam AD/ART Partai Golkar dari partai itu sendiri yang dibentuk pada tahun 1964 tepatnya awal berdirinya partai ini.

Ketika dalam tubuh partai PDIP terjadi gejolak politik yang mengakibatkan adanya intervensi dari pemerintah yang masih mendominasi pembentukan partai ini, berbeda dengan PAN yang terlahir dalam kemandirian dan karena konteks reformasi, tetapi pembentukan Partai Golkar dapat kita maknai sebagai keinginan rezim yang berkuasa guna mempersiapkan para anggotanya sebagai mesin politik. Dari sisi kemandirian, jelas ini tidak sebagaimana berdirinya PDIP dalam logika kejadian yang kedua, atau PAN yang benar-benar mandiri dari intervensi negara. Sehingga perubahan hanya bersifat paradigmatik tadi, bukan pada ranah keberlanjutan organisasi.

Partai juga berusaha mandiri dalam proses pengambilan keputusan, mengendalikan seluruh proses dan dinamika organisasi dengan menghilangkan struktur Dewan Pembina yang pada zaman dahulu merupakan salah satu instrumen rezim untuk mengendalikan Golkar. Saat ini, peran Dewan Pembina diisi oleh Dewan Penasihat yang hanya memiliki kewenangan terbatas terhadap Pengurus Harian.

Meskipun Golkar berusaha menampilkan diri namun dengan melihat bahwa Partai Golkar secara organisatoris dan kelembagaan adalah kelanjutan dari Golkar yang kelahirannya diracang sebagai mesin politik pemerintah, maka dapat diambil kesimpulan bahwa sebagaimana di tingkat pusat, kelahiran dan pertumbuhan Golkar di Daerah Istimewa Yogyakarta tidak menunjukkan bahwa partai ini terinstitusionalisasi.

\section{Sumber Pendanaan Partai}

Dores Cordes (Pipit R.Kartawidjaja \& Mulyani, Kisah mini sistem kepartaian [Closs,2003]) memilah penerimaan dana partai politik dalam dua jenis sumber pendanaan seperti swadana dan dana eksternal Salah satu tolak ukur sejauh mana otonomi suatu partai politik dapat dilihat dari sumber 
pendanaan partai poliik (the financing of political party). Partai politik yang mengandalkan mayoritas pendanaan partai dari unsur - unsur eksternal partai, minsalnya pemerintah dan berbagai lembaa donor, memperlihakan kurang otonomnya partai tersebut sebaliknya semakin mampu sebuah partai politik mengali sumber pendanaan dari internal, minsalnya melalui iuran wajib anggota partai dan simpatisannya yang tidak mengikat, partai tersebut relative mampu menjaga kemandiriannya.

Pernyataan ini diperkuat juga oleh W.Philips Shively mengatakan ada 6 sumber pendanaan yang mana dari keenamnya dapat melihat serta mengukur sumber pendanaan DPD partai Golkar D.I.Y , diantaranya; keuangan public (public financial), iuran keanggotaan individual (individual membership), uang suap dan komisi (bribes and kickbacks), bantuan dari kelompok - kelompok kepentingan, keuntungan dari usaha bisnis yang dijalankan partai.

Pada kenyataanya, partai-partai yang ada diera transisi di Indonesia masih banyak mengalami kendala dalam soal pendanaan, dimana untuk menjadi partai yang besar dengan berbagai kegiatan beragam dibutuhkan dana dana jumlah yang besar. Dari segi ketersediaan dana untuk menghidupi jalannya organisasi, pendanaan golkar selama masa orde baru relatif terjamin dan ini semua tidak terlepas dari eksistensi parai golkar sebagai partainya pemerintah yang berkuasa pada masa itu.

\section{Pendanaan dan Kemandirian Partai}

Elemen kedua dari aspek systemness ini adalah masalah sumber dana kepartaian. Bukan rahasia lagi bahwa uang adalah mother's milk of politics. Dengan dana yang mencukupi maka partai diasumsikan dapat berbicara dan berbuat banyak dalam posisinya sebagai aktor dalam sistem politik. Dengan dana yang memadai, partai dapat survive dan menjalankan berbagai fungsi yang dibebankan pada pundaknya. Uang tidak harus selalu bermakna negatif dalam politik, karena realitasnya untuk dapat bermain cantik dan bersihpun tetap dibutuhkan pendanaan yang kuat.

Kemampuan partai untuk survive memang akan berbanding lurus dengan kemampuan mereka dalam menggalang dana. Sementara independensi dan otonomi partai terhadap negara dan aktor eksternal akan sangat tergantung pada bagaimana mereka mampu menggalang dana yang independen dan otonom, baik dari negara maupun dari sumber-sumber yang memiliki kepentingan dan agenda tersendiri.

Dengan pendanaan yang mandiri, partai dapat menjalankan berbagai program dan kegiatan secara otonom tanpa terinterupsi oleh kepentingan negara. dimana partai akan relatif steril dari intervensi dan kehendak negara yang notabene menjadi penyandang dana mereka, maka partai tidak perlu menanggung beban struktural yang menentukan derajat otonominya terhadap negara. Dengan kata lain partai relatif terjaga dari kooptasi negara.

\section{Sumber Pendanaan Politik Dalam Partai Golkar DIY}

Mengelola partai politik jelas memerlukan dana yang besar baik untuk membiayai kegiatan partai sehari-hari maupun terutama untuk keperluan kampanye pemilihan umum. Karena itu partai politik niscaya harus mencari dana baik dari iuran anggota maupun kontribusi para simpatisan. Tidaklah mengeherankan bila partai politik acapkah juga disebut sebagai sarana mencari dana. Akan tetapi partai politik dinilai tidak memiliki akuntabilitas publik yang jelas.

Partai politik sebagai sarana mencari dana sudah barang tentu tidak berlaku bagi semua partai politik karena bila tidak memiliki kursi dalam jumlah yang memadai dalam DPR/D tentu tidak memiliki sarana untuk mempengaruhi pihak lain. Baik UU tentang Parpol maupun UU Pemilu sudah mengatur jenis, asal/sumber, dan jumlah penerimaan dana. Sebagai badan publik partai politik diwajibkan oleh UU Parpol untuk melaporkan penerimaan dan penggunaan dana setiap akhir tahun kepada Mahkamah Agung.

Secara formal, aturan pendanaan politik dalam partai ini yang diatur dalam pasal 46 Anggaran Rumah Tangga Partai Golkar. Di situ tertulis bahwa sumber-sumber keuangan partai terdiri atas (1) iuran wajib; (2) iuran sukarela; dan (3) sumbangan perorangan; (4) sumbangan badan atau lembaga; (5) usaha-usaha lain yang sah; dan (6) bantuan dari anggaran negara/daerah.

Sumber pendanan merupakan faktor penting yang menyebabkan Golkar tidak mandiri selama kiprahnya pada masa Orde Baru, dari segi ketersediaan dana untuk menghidupkan jalannya organisasi, pendanaan Golkar selama orde baru relatif terjamin. Ini tidak lepas dari eksistensi golkar sebagai sebuah partai pemerintah, dengan pendanaan yang disokong penuh oleh kekuasaan. Sumber dana Golkar selain akses yang dimilikinya pada kekuasaan baik di lingkungan pemerintah maupun 
badan - badan usaha milik negara, serta juga berasal dari pengusaha swasta. Jenis sumber aliran dana Golkar selama kurun Orde Baru didominasi oleh dana dari sumber - sumber eksternal, iuran anggota yang umumnya menjadi sumber pendanaan utama sebuah partai politik tidak dijalankan oleh partai, kalaupun ada pemasukan dari anggota umumnya lebih bersifat sumbangan sukarela dan bukan iuran wajib anggota.

Dalam kaitannya dengan kemandirian partai, dari sumber dana mayoritas keuangan partai berasal, memiliki berbagai konsekuensi. Dimana sebagian besar keuangan partai golkar DIY ternyata berasal dari bantuan pemerintah, artinya semakin sulit partai golkar menjadi otonom terhadap pemerintah. Sumber dana partai golkar DIY juga mendapat bantuan dari daerah dan pusat besar nominal bantuan yang diberikan daerah tergantung dari jumlah kursi yang ada di DPRD, dalam hal ini pemerintah Daerah Tingkat I membantu sebesar Rp.20.000.000'- (Dua Puluh Juta Rupiah) per kursi didalam satu tahun. Sedangkan bantuan dari pusat sebesar Rp.5.000.000'- per bulan dalam setiap bulannya.

Akan tetapi dilihat dari segi kemandirian partai Golkar dalam segi pendanaan partai prioritas utama, partai masih mengantungkan diri kepada pemerintah sehingga partai golkar DPD DIY masih berada pada titik lemah di dalam kemandirian internal partai aspek ini dilihat dari besarnya dana yang diperoleh dari pemerintah daerah, hal ini dapat katakan bahwa partai golkar telah terlembaga, namun secara internal masih memiliki titik lemah dilihat dari aspek sumber dana partai yang terlihat dari besarnya bantuan yang didapatkan oleh partai ini dari pemerintah. Hal ini diperkuat dari hasil wawancara dengan Sekretaris DPD partai Golkar DIY dan Wakil Sekretaris Biro Pemenangan pemilu.

\section{Kepemimpinan Dalam Partai Golkar}

James M.Blade mengatakan bahwa kepemimpinan adalah kemampuan yang sanggup menyakinkan orang lain supaya bekerjasama dibawah pimpinannya sebagai tim untuk mencapai tujuan tertentu (silabus materi kuliah Kepemimpinan; Tunjung Solaksono). Samuel P.Huntington \& Joan Nelson (partisipasi politik dinegara berkembang, 1994: hal.13) juga mengemukakan tentang teori mobilitas kepemimpinan dalam suatu partai; Dimana seorang pemimpin politik yang dapat memobilisasi pendukung - pendukung mempunyai posisi yang sangat berbeda dengan pemimpin yang tidak dapat berbuat hal yang sama dan tindakan - tindakannya mempunyai konsekuensi konsekuensi yang sangat berlainan bagi sistem politik.

Partai yang efektif terletak pada bagaimana relasi antara pemimpin dan partai politik. Melihat asal muasal sebuah partai, Panebianco menekankan satu bagian penting yang dimainkan oleh sesuatu yang disebut karisma di dalam pembentukan partai. Maksudnya, dimana sebuah partai pada awalnya tercipta dari sebuah kendaraan politik bagi seorang pemimpin karismatik. Menurut Panebianco, karisma ini dalam tahap awal perkembangan partai memang bersifat positif dan diperlukan karena akan memainkan peranan pemimpin dalam partai Golkar D.I.Y.

\section{Peranan Pemimpin}

Dalam hal ini peranan pemimpin partai Golkar DPD DIY dalam pengambilan keputusan tergantung dari permasalahan yang harus diputuskan dan hal - hal yang sudah merupakan aturan yang tercantum dalam AD/ART internal partai, yang mana keputusan tersebut tidak perlu dirapatkan lagi. Tapi pada dasarnya organisasi atau partai jelas keputusan tertinggi berada dibawah Musda (musyawarah daerah) pada rapat pleno, karena rapat pleno itu merupakan semacam forum untuk mengambil suatu keputusan setelah Musda. Dalam hal pengkrekrutan ini tergantung kepada keinginan yang bersangkutan untuk menjadi anggota partai setelah itu dijalankan sesuai dengan prosedur partai.

Sedangkan dalam pemberhentian anggota partai mengikuti kriteria yang sudah tercantum dalam AD/ART internal partai; pertama, karena yang bersangkutan mengundurkan diri, kedua, meninggal dunia, ketiga, melanggar peraturan organisasi yang telah tercantum dalam AD/ART, seperti halnya:

1) Adanya anggota partai yang pindah kepartai lain.

2) Melakukan pelanggaran hukum dan memenuhi hukum tetap.

3) Peranan Sosial, sedangkan menurut Soerjono Soekanto bahwa kepemimpinan merupakan hasil organisasi social yang telah terbentuk atau sebagai hasil dinamika interaksi sosial. 
Untuk mewujudkan ideologi tujuan partai Golkar DIY membutuhkan organisasi seperti; partai politik, gerakan sosial, asosiasi masyarakat, kelompok gerilya, guna menggerakkan sumber daya material untuk mengkoordinasikan sejumlah kegiatan, yang intinya agar suatu perubahan dapat tercipta dengan baik para pemimpin partai golkar DIY mengkombinasikan ideologi dengan organisasi. Hal ini jelas menciptakan suatu suasana perasaan baru, identitas bersama dan memberikan dasar pembenaran bagi hak para pemimpin baru untuk memerintah masyarakat.

Ketika penulis mewawancarai Bapak Heroe.TH, Biro Pemenangan Pemilu mengatakan bahwa partai golkar DIY berperan aktif dalam penyelenggaraan bakti social kepada masyarakat, hal ini terbukti pada tanggal 22 Februari 2008 partai Golkar DIY mengadakan acara " Jalan Sehat Bareng Prabowo", penyerapan aspirasi masyarakat seperti di daerah Kulon Progo minsalnya, permasalahan masyarakat di tanggapi dengan serius oleh kader - kader partai Golkar DIY, dimana bantuan tersebut berupa penanganan air minum dan renovasi jalan bagi masyarakat setempat, penanganan korban bencana gempa di DIY yang terjadi pada bulan mei 2006.

\section{Sistem mekanisme organisasi partai}

Didalam kepengurusan partai yang diadakan 5 tahun sekali, partai akan mengadakan Musda (musyawarah daerah) untuk tingkat daerah dan untuk ditingkat nasional (Munas), musyawarah daerah akan memilih kepengurusan di dewan pimpinan daerah sama halnya seperti musyawarah nasional akan memilih dewan pusat. Partai Golkar dengan paradigma barunya tidak hanya berhenti pada level wacana. Namun dalam beberapa dimensi DPD Golkar Propinsi Daerah Istimewa Yogyakarta telah berupaya untuk menempatkan aturan main di atas kepentingan personal seorang pemimpin. Kepatuhan terhadap keputusan partai sedapat mungkin dilakukan agar kepentingan pribadi pemimpin tidak lantas membajak organisasi sebagai kendaraan untuk mewujudkan ambisi pribadinya.

Dalam hal ini pemimpin partai Golkar DIY berperan dan berusaha untuk mengembangkan orientasi baru yang berkomitmen pada semangat reformasi yang berintikan keadilan, demokratisasi, dan transparansi. Pengembangan konsep paradigma baru tersebut ternyata bukan hanya di atas kertas. Setidaknya, dalam beberapa hal telah dicoba diimplementasikan di lapangan. Pertama, Golkar mencoba untuk mewujudkan proses pemilihan ketua umum melalui mekanisme demokratis. Kedua, Golkar menyatakan telah melakukan disconnection terhadap sistem kekuasaan lama yang terpusat pada orang seorang, sekaligus melaksanakan koreksi yang terencana, melembaga, dan berkesinambungan terhadap penyimpangan masa lalu. Ketiga, Golkar juga menghapus adanya Lembaga Dewan Pembina, Dewan Pertimbangan dan Dewan Penasihat. Selanjutnya Golkar ingin tampil mandiri dan demokratis dalam pengambilan keputusan dengan menghapus mekanisme tiga jalur, yang waktu itu dikenal dengan ABG (ABRI, Birokrasi, dan Golkar).

Dalam level pusat, kita dapat melihat bahwa dibanding partai-partai besar yang lain, Partai Golkar adalah partai yang tidak terlalu memusingkan figur pimpinan. Jika PDIP dianggap sebagai personalisasi kekuasaan Megawati, Amien Rais yang identik dengan PAN, atau Gus Dur yang sangat lekat dengan PKB, maka dalam Golkar tradisi seperti itu tidak terlihat, paling tidak hingga kepemimpinan Jusuf Kalla saat ini. Disini penulis menyimpulkan jelas adanya kemandirian partai Golkar DIY dan keterlembagaannya menurut penulis telah terlembaga sesuai dengan teori Randall dan Svansad mengenai hak dan kewajiban seorang anggota organisasi partai, proses pelaksanaan fungsi-fungsi partai politik dan cara organisasi tumbuh juga berkembang, sumber daya organisasi, peran individual pemimpin berbanding organisasi partai, peran faksi-faksi berbanding partai secara keseluruhan, dan dampak klientilisme.

\section{Faksionalisme di Tubuh Golkar}

Dalam teori Maurice Duverger menjelaskan bahwa; ada dua bentuk dari struktur tidak langsung yaitu terdiri dari organisasi - organisasi yang umumnya didasarkan atas suatu kelas yang sama dan kedua merupakan bentuk federasi dengan menghimpun berbagai macam kelas dan bahkan kepentingan anggota masyarakat atau golongan pendukungnya.

Yang menurut Randall dan Svansand teori ini dinamakan dengan Faksionalisme, dimana di dalam tubuh DPD Golkar D.I.Y sebenarnya terdapat juga prinsip faksionalisme yang sesuai dengan kedua teori diatas, hal ini dapat dilihat lewat tiga entry point. faksi yang dibangun atas dasar loyalitas kelompok (terutama kelompok primordial) yang dapat dilihat dari unsur-unsur awal pembentuk partai ini. Dari pintu masuk ini maka dapat dipahami jika sebuah organisasi partai yang tersusun dari banyak 
elemen organisasi yang sebelumnya tidak memiliki keterkaitan satu sama lain akan memunculkan faksionalisme dalam tubuh partai ini.

Dan fraksi juga dapat terbangun atas dasar kesamaan visi tentang bagaimana mewujudkan masa depan bangsa atau organisasi (Zaetun \& Mar'iyah, 2020). Visi dalam beberapa hal berbeda dengan ideologi karena visi lebih mengarahkan pandangannya terhadap masa depan yang harus diwujudkan, sementara ideologi lebih banyak berkutat tentang bagaimana cara atau jalan untuk mencapai tujuan dan cita-cita tersebut, juga faksionalisme dalam tubuh Golkar dapat dijelaskan kemunculannya sebagai kombinasi antara faksi historis yang bersifat statis dan faksi yang bersifat lebih dinamis karena muncul sebagai konsekuensi isu-isu kontemporer dalam tubuh partai.

Dalam tubuh Golkar, budaya faksi memperlihatkan esensi tersebut. Keberadaan faksi dalam tubuh Golkar bersifat primordial. Faksi keturunan. Purnawirawan militer dan anak-anaknya adalah KBA (Keluarga Besar ABRI). Pensiunan pegawai negeri dan organisasi turunannya adalah KBB (Keluarga Besar Birokrasi. Kader anak rakyat biasa yang bukan militer dan pegawai negeri itulah KBG (Keluarga Besar Golongan Karya). Itulah representasi pilar ABG dalam tubuh Partai Golkar yang meskipun usianya mencapai empatpuluhan tahun, namun faksionalisme yang bersifat historis dan statis ini tetap mewujud dan eksis hingga saat ini.

Faksi juga dapat terbangun atas dasar kesamaan visi tentang bagaimana mewujudkan masa depan bangsa atau organisasi. Visi dalam beberapa hal berbeda dengan ideologi karena visi lebih mengarahkan pandangannya terhadap masa depan yang harus diwujudkan, sementara ideologi lebih banyak berkutat tentang bagaimana cara atau jalan untuk mencapai tujuan dan cita-cita tersebut.

Dalam pendekatan kedua ini, maka faksionalisme yang terbentuk akan bersifat lebih dinamis, atau bisa juga disebut cair. Artinya, sebuah faksi yang terbentuk tidak mengental dan statis sebagaimana faksi yang terbentuk dalam perspektif historis, namun justru isu yang akan bersifat determinan terhadap eksistensi faksi. Dengan kata lain, faksi-faksi yang terbentuk dalam suatu isu kontemporer bisa jadi berubah begitu menghadapi isu yang lain.

Untuk saat ini partai Golkar DIY ada pengelompokkan faksi - faksi terhadap proses pencalonan seorang pemimpin (calon Presiden), namun faksi - faksi ini akan menjadi satu apabila sudah menemukan calon pemimpin (presiden) yang mekanismenya jika telah terpilih salah satu calon maka semua DPD harus mendukung keputusan partai.

\section{Efek Klientilisme dalam Partai Golkar}

Efek klientilisme adalah dampak dari relasi yang dibentuk antara organisasi masyarakat yang berafiliasi ke dalam partai Golkar. Angelo Panebianco mengemukakan bahwa institusionalisasi dipandangnya sebagai cara dimana organisasi menjadi solid yang bertujuan agar terjaganya keawetan dan kelangsungan suatu tujuan bagi sejumlah pendukung organisasi itu sendiri. Melihat dinamika kelembagaan internal partai, maka kita harus melihat bagaimana efek klientilisme terhadap partaipartai tersebut. Sebagaimana fraksi, dan seringkali dikaitkan dengannya, fenomena klientilisme ini menyebar di hampir semua masyarakat dunia ketiga serta partai-partai politik yang ada di dalamnya.

Dalam relasi antara elit pusat dan daerah, juga tidak terlalu menampakkan jejak klientilisme. DPD Provinsi Lampung dan DIY, dua daerah yang selama ini dikenal sebagai basis dukungan terhadap Akbar Tandjung, sama sekali tidak mendapat "gangguan" yang cukup berarti. Bahkan dua pengurus dalam DPP Golkar periode 2004-2009 adalah orang Yogya, yaitu Sultan Hamengkubuwono $\mathrm{X}$ dan GBPH Joyokusumo, kaka beradik penguasa Kasultanan Yogyakarta. Namun dalam hal ini sebagai satu organisasi partai secara struktur harus mendukung kebijaksanaan pusat, walaupun yang diinginkan oleh pusat belum sepadan dengan dukungan DPD Partai Golkar di Propinsi DIY.

Dengan demikian, dapat disimpulkan bahwa tidak ada efek klientilisme dari faksionalisme yang terjadi dalam tubuh DPD Partai Golkar Propinsi Daerah Istimewa Yogyakarta, keberadaannya dapat membahayakan proses institusionalisasi dalam sebuah organisasi.

\section{KESIMPULAN}

Setelah melakukan analisa data terhadap hasil wawancara dengan pengurus - pengurus partai Golkar di DPD D.I.Y, maka penulis berdasarkan definisi operasional dapat membuat kesimpulan bahwa Kesisteman di Dalam DPD Partai Golkar D.I.Y adalah: Partai Golkar berusaha menampilkan diri namun dengan melihat bahwa Partai Golkar secara organisatoris dan kelembagaan adalah kelanjutan dari Golkar yang kelahirannya diracang sebagai mesin politik pemerintah, maka dapat 
diambil kesimpulan bahwa sebagaimana di tingkat pusat, kelahiran dan pertumbuhan Golkar di Daerah Istimewa Yogyakarta tidak menunjukkan bahwa partai ini terinstitusionalisasi. Dari segi kemandirian partai Golkar dalam segi pendanaan partai prioritas utama, partai masih mengantungkan diri kepada pemerintah sehingga partai golkar DPD DIY masih berada pada titik lemah di dalam kemandirian internal partai aspek ini dilihat dari besarnya dana yang diperoleh dari pemerintah daerah, hal ini dapat katakan bahwa partai golkar telah terlembaga, namun secara internal masih memiliki titik lemah dilihat dari aspek sumber dana partai yang terlihat dari besarnya bantuan yang didapatkan oleh partai ini dari pemerintah.

Adanya kemandirian partai Golkar DIY dan keterlembagaannya menurut penulis telah terlembaga sesuai dengan teori Randall dan Svansad mengenai hak dan kewajiban seorang anggota organisasi partai, proses pelaksanaan fungsi-fungsi partai politik dan cara organisasi tumbuh juga berkembang, sumber daya organisasi, peran individual pemimpin berbanding organisasi partai, peran faksi-faksi berbanding partai secara keseluruhan, dan dampak klientilisme. Kepengurusan partai di tingkatan pusat terjadi faksionalisme yang luarbiasa, namun sebaliknya, partai Golkar di DIY sama sekali tidak menunjukkan gejala faksionalisme tersebut. Meskipun faksionalisme yang dibangun pada level pusat oleh sebagian elit partai demikian kentara, namun faksionalisme tersebut hampir tidak menunjukkan efeknya di DPD Golkar DIY. Ketidakadaan efek klientilisme dari faksionalisme yang terjadi dalam tubuh DPD Partai Golkar Propinsi Daerah Istimewa Yogyakarta, yang mana keberadaannya dapat membahayakan proses institusionalisasi dalam sebuah organisasi sehingga dampak dari relasi yang dibentuk diantara organisasi masyarakat dapat berafiliasi ke dalam partai Golkar yang akan menimbulkan pengelompokan didalam tubuh suatu organisasi.

Saran saran yang dapat disampaikan terkait dengan hasil penelitian ini adalah bahwa, Partai Golkar mampu bertahan hidup dan berperan dalam sistem kepolitikan yang demokratis, serta meraih dukungan signifikan pada dua kali pemilu era reformasi. Untuk kedepannya parta Golkar perlu terus memperkuat kelembagaan dan mengkonsolidasi seluruh sumber dayanya serta menerapkan (adjustable) dalam menghadapi lingkungan politik yang terus berubah dan persaingan antar partai yang semain tajam. Partai Golkar harus mengubah pola pikir dan sikapnya yang semata - mata hanya berorientasi pada kekuasaan, dan secara sungguh - sungguh menerapkan paradigm barunya yang resfonsif terhadap aspirasi dan kepentingan rakyat.

\section{REFERENSI}

Akhbar, A., Miranda, A., Fahrezi, A. N., \& Jannah, M. (2020). Analisis Dampak Sistem Multipartai dalam Implementasi Sistem Pemerintahan Presidensil di Era Jokowi \& Jusuf Kalla. TheJournalish: Social and Government, 1(1), 28-32.

Angelo Panebianco. (1998). Political Parties: Organization and poer, Cambrigde University Press, cambrigde

Berutu, A. G., Metodologi, P., Kualitatif, Muhadjir, N., Sekolah, B., Uin, P., \& Jakarta, H. (2017). Metodologi Penelitian Noeng Muhajir. https://doi.org/10.13140/RG.2.2.20452.73607

Darmawan, J. J., Jati, B. B. P., Darmawan, J. J., \& Jati, B. B. P. (2012). Kecenderungan Pemberitaan tentang Reshuffle Kabinet Indonesia Bersatu II di SKH Jawa Pos dan SKH Kompas. Jurnal ILMU KOMUNIKASI, 9(2), Article 2. https://doi.org/10.24002/jik.v9i2.168

IKPNI, I. (2019). Pemberontakan PRRI/Permesta. IKPNI. http://ikpni.or.id/post-kilassejarah/pemberontakan-prri-permesta/

koran.tempo.co/, https://koran. tempo. co/. (2004, November 29). Dari Sekber Sampai Partai Golkar-Nasional-Koran.tempo.co.

Tempo. https://koran.tempo.co/read/nasional/27973/dari-sekber-sampai-partai-golkar

Nurdamarsah, T. (2018). Politik Masyumi Di Masa Demokrasi Parlementer 1950 - 1959 Nurdamarsah | Herodotus: Jurnal Pendidikan IPS. https://journal.lppmunindra.ac.id/index.php/herodotus/article/view/2874

Paige Johnson Tan. (1976). "Political parties and the consolidation of Democracy in Indonesia", Working Paper, Department of political Science, University of North Carolina, Wilmington, tanpa tahun, hal. 6. Lihat juga Giovanni Sartori, Parties and Party System: A framework for Analysis, (Cambridge, Cambridge University Press. 
Rahagi, E. (2019). Marketing Politik Calon Legislatif Milenial Partai Golkar Pada Pemilu Legislatif 2019 Studi Kasus:Pemenangan Abraham Sridjaja Sebagai Caleg Dpr Ri Dapil 1 Jawa Timur (SURABAYA-SIDOARJO). http://repository.unair.ac.id/88092/

Richard S. Katz dan Peter Mair. (2003). The Ascendency of the Party in Public Office: Party Organizational Change in Twentieth-Century Democracies, dalam Richard Gunther,Jose Ramon Montero,dan Juan J. Linz, Political Parties: Old Concept and New Challenges, New York: Oxford University Press

Sumarwati, I. (2011). Peran elit lokal terhadap kemenangan Golkar di Kabupaten Sragen pada Pemilu 1992 dan 1997. https://digilib.uns.ac.id/dokumen/20576/Peran-elit-lokal-terhadapkemenangan-Golkar-di-Kabupaten-Sragen-pada-Pemilu-1992-dan-1997

Suyatno, W. T. (2006). Sentral Organisasi Karyawan Swadiri Indonesia. Partai Golongan Karya. https://www.partaigolkar.com/sentral-organisasi-karyawan-swadiri-indonesia/

Solaksono, Tunjung. (2000).Konflik Pusat-Daerah dalam Rekrutmen Elit Lokal: Studi Kasus Pemilihan Gubernur DIY 1998, Skripsi, Jurusan Ilmu Pemerintahan FISIPOL UGM, Yogyakarta

Saifuddin Azwar. MA., "Metode Penelitian" Pustaka Pelajar, Yogyakarta, hal.40.

Soerjono Soekanto. (2003). Sosiologi suatu pengantar . PT.raja Grasindo Persada, Jakarta.

Tandjung. Akbar. (2007) The Golkar Way: Survival Partai Golkar di Tengah Turbulensi Politik Era Transisi, PT.Gramedia Pustaka Utama,Jakarta.

Zaetun, S., \& Mar'iyah, C. (2020). Politik Kekerabatan Dalam Keterwakilan Perempuan Pada Rekrutmen Politik Partai Nasdem Pada Pemilu 2019. TheJournalish: Social and Government, 1(3), 119-129. 